\title{
Processing of Makhana and Value Chain Financing in Bihar
}

\author{
Ravi Atal ${ }^{1 *}$, Shridhar Patil ${ }^{1}$, Subodh Kumar', Suman Lata ${ }^{2}$ and Sonam Roy ${ }^{1}$ \\ ${ }^{1}$ Department of Extension Education, Bihar Agricultural University, \\ Sabour, Bhagalpur, Bihar-813210, India \\ ${ }^{2}$ Department of Soil Science and Agricultural Chemistry, Bihar Agricultural University, \\ Sabour, Bhagalpur, Bihar-813210, India \\ *Corresponding author
}

\begin{abstract}
A B S T R A C T
This study was conducted to analyse the status of Makhana processing and its value chain financing in Bihar. Findings of the study revealed that almost 100 per cent of Makhana is processed manually and the adoption of Makhana processing machines was totally absent. The net profit earned by processing of each quintal of raw Makhana seeds is very less in comparison to the share in consumers' price.Contrary to the Makhana production; the women participation in Makhana processing was much significant. Women execute 74.45 per cent of roasting activity and 62.36 per cent of grading activity. Here child labour also contributed 21.54 and 13.08 per cent in grading and first roasting, respectively. In case of Makhana processing, the major constraints were lack of affordable and efficient processing machines dependence on private money lenders with high interest rates for procurement of raw material. Analysis of Makhana value chain financing practice revealed that private money lenders were major financers of value chain who financed 85 per cent of makhana processors. Based on this study, value chain financing to the Makhana processors can be characterized by small loan amounts (average loan size of Rs 257083 to 268333), high interest rates (ranging between 40 to $45 \%$ per annum) and one time payments.
\end{abstract}

\section{Keywords}

Makhana,

Financing,

Processing

Article Info

Accepted:

10 April 2020

Available Online:

10 May 2020

\section{Introduction}

Makhana (Euryale ferox) is a perennial aquatic plant belonging to the family of Nympheaceae, genus Euryale having its origin in Eastern and Southern Asia. In India, Makhana grows in all the parts of country having diverse agro-climatic conditions including Rajasthan, Jammu Kashmir and Madhya Pradesh. However, the commercial cultivation of Makhana crop is mostly limited to the Northern parts of Bihar as well as adjoining regions of West Bengal and Assam.

As per the estimates of the ICAR-National Research Centre for Makhana (2010), total area under Makhana cultivation in India is estimated to be around 15000 hectare producing 1,20,000 metric tons Makhana seeds annually, which after processing yields 
40,000 metric tons Makhana pop. The estimated value of the production at farmers end is Rs. 2500 million and it generates revenue of Rs 5500 million at traders' level. The Bihar state has almost gained monopoly in production of Makhana in the country and accounts for more than 80 per cent of the total production (Kumar et. al., 2012). Despite of that, it has been reported that the area under Makhana crop has declined sharply by 35 per cent in past few decades from 20,000 ha to 13,000 ha (Singh, 2014).

Makhana production is facing number of issues including inefficient marketing channels (Rahaman et. al, 2019), high cost of harvesting (ICAR-Research Complex for Eastern Region, 2018), shortage of organized Makhana processing industry and related malpractices (Minten et. al, 2010) etc. This study was conducted to understand the status of Makhana processing and its value chain financing so as to suggest suitable strategies to minimize the costs and increase profitability of Makhana production and processing enterprises.

\section{Materials and Methods}

This study was conducted using descriptive research design during the year 2017-18 and 2018-19 in Purnea, Saharsa and Darbangha districts of Bihar using a randomly selected sample of 60 Makhana processors. The respondents were selected using multistage random sampling. From each district one block was selected purposively on the basis of estimated area under Makhana cultivation. Subsequently from each block two to three villages was selected purposively with the same criteria of estimated area and production.

The aim of studying economics of Makhana processing activity and understand the profitability of Makhana based processing system and identify the major reason behind high cost of processing. Therefore, deviating from standard procedure of dividing cost of processing into fixed and variable cost an attempt was made in this study to identify and document the cost associated with each component of Makhana processing activity was analyzed with the help of schedule developed for this study.

Further the data related to work participation of male female and child laborers was collected in terms of per cent work contribution. The data related to value chain financing including, size of loan amount, source of loans, loan duration, documentation and collateral security were also collected using semi structured interview schedule.

\section{Results and Discussion}

Work participation of adult male, female and child labourers in the Makhana processing activity was also studied. Contrary to the Makhana production activity, the work participation pattern in Makhana processing was found to be entirely different. It was observed that adult male labourers carried out majority of work related to washing of raw seed $(74.03 \%)$, Sun drying and popping (100.00\%)whereas women labourers' participation was found to be significantly high in grading $(62.36 \%)$, first roasting $(74.45 \%)$, and second roasting $(72.19 \%)$.One of the serious issues of concern in Makhana processing is participation of child labourers. It was found that child labourers' participation was significant in washing (12.83\%), grading(21.54\%), first $(13.08 \%)$ as well as second roasting $(14.41 \%)$ of seeds.

Makhana processing is the labour intensive activity without any kind of processing mechanization. The analysis of processing activities reveals that, for processing each quintal of raw seed of Makhana, total cost of 
Rs. 10296 is incurred of which majority of cost (Rs. 7783) pertains to the purchase of raw seeds, followed by labour charges (Rs. 2064). Cost associated with other aspects like transportation, processing equipment, room rent, procurement of packing material, electricity etc. were far lower and each of these contributed less than 5 per cent of total cost of processing. The net returns calculated using the findings of the study related to pop recovery percentage and average sale price. The average pop recovery percentage was 40$45 \mathrm{~kg} / \mathrm{qtl}$ of raw seeds and average sale price was rupees 250 per $\mathrm{kg}$ of popped Makhana.

Analysis of economics of processing activity revealed that the processors earn Rs. 204.14 per/q of raw seed processing after deducting cost of processing from the gross return (i.e. Rs10675.).

Table.1 Work Participation in Processing $(n=60)$

\begin{tabular}{|c|l|c|c|c|}
\hline Sl. No. & Activity & \multicolumn{3}{|c|}{ Per cent work contribution } \\
\hline & & Adult male & Adult female & Children \\
\hline $\mathbf{1}$ & Washing & 74.03 & 13.14 & 12.83 \\
\hline $\mathbf{2}$ & Sun Drying & 100.00 & 0.00 & 0.00 \\
\hline $\mathbf{3}$ & Grading & 16.10 & 62.36 & 21.54 \\
\hline $\mathbf{4}$ & First Roasting & 12.47 & 74.45 & 13.08 \\
\hline $\mathbf{5}$ & Seconding Roasting & 13.40 & 72.19 & 14.41 \\
\hline $\mathbf{6}$ & Popping & 100.00 & 0.00 & 0.00 \\
\hline
\end{tabular}

Table.2 Economics of Makhana processing $(n=60)$

\begin{tabular}{|c|l|c|c|}
\hline Sl. No. & Items & $\begin{array}{c}\text { Mean cost } \\
\text { (Rs./q raw seed) }\end{array}$ & Per cent \\
\hline $\mathbf{1}$ & Labour Wages & 2064 & 20.05 \\
\hline $\mathbf{2}$ & Transportation & 82 & 0.80 \\
\hline $\mathbf{3}$ & Processing equipment & 45 & 0.44 \\
\hline $\mathbf{4}$ & Packaging & 73 & 0.71 \\
\hline $\mathbf{5}$ & Fuel & 204 & 1.98 \\
\hline $\mathbf{6}$ & Room Rent & 30 & 0.29 \\
\hline $\mathbf{7}$ & Electricity & 16 & 0.16 \\
\hline $\mathbf{8}$ & Cost of raw seed & 7783 & 75.59 \\
\hline $\mathbf{9}$ & Total cost of processing & 10296 & - \\
\hline $\mathbf{1 0}$ & Average production of popped Makhana per & $40-45$ & - \\
\hline & quintal & & \\
\hline $\mathbf{1 1}$ & Sale price (Rs./Unit) & 10,675 & - \\
\hline $\mathbf{1 2}$ & Gross selling cost & 204.14 & - \\
\hline $\mathbf{1 3}$ & Net Income per quintal popping & $1: 1.03$ & \\
\hline $\mathbf{1 4}$ & B:C ratio & & - \\
\hline
\end{tabular}


Table.3 Financing practice of processor $(n=60)$

\begin{tabular}{|r|l|c|c|c|c|}
\hline $\begin{array}{l}\text { Sl. } \\
\text { No. }\end{array}$ & Financing Body & Frequency & $\begin{array}{c}\text { Per } \\
\text { scent }\end{array}$ & $\begin{array}{c}\text { Average loan } \\
\text { amount }\end{array}$ & $\begin{array}{c}\text { Average \% interest rat } \\
\text { per annum }\end{array}$ \\
\hline $\mathbf{1}$ & Money Lender & 51 & 85.00 & 257083 & 44.64 \\
\hline $\mathbf{2}$ & Financial Institution & 0 & 0.00 & 0 & 4 to 18 \\
\hline $\mathbf{3}$ & Fellow Farmer \& Friends & 09 & 15.00 & 268333 & 40.44 \\
\hline
\end{tabular}

In this study the average rate of interest charged by various money lenders to the borrowing processors was also studied. The rate of interest charged by the money lender is 2 to 5 percent hence the table 2 reveals that the average interest charged by private money lenders was 44.64 percent. Due to this fact the processor after processing of Makhana sell pop immediately even if they are getting low rate so that they can repay their debts paid.

Though the interest charged by the fellow farmers was relatively low but it was also exorbitantly high in absolute terms. Average interest rate charged by fellow farmers and friends was 40.44 percent. However, the interest rate charged by the banking institution were relatively small ranging between 4 to 18 percent but unfortunately none of the processors take advantage of it.

This study emphasized on describing the existing scenario of Makhana processing. It was observed that the cost of labor wages associated with Makhana processing constitutes nearly 20 percent of total cost of cultivation. This cost can be minimized by mechanization of Makhana processing activity.

The farmers preference to private money lenders despite high interest rate have number of policy implications of which important one is that there is need to improvise a relation between financial institutions and value chain actors including Makhana growers and processors so as to make financial lone more accessible and affordable with minimal paperwork.

\section{References}

Anonymous.2010. ICARNational Research Centre for Makhana, Darbhanga.

Anonymous.2018. ICAR ResearchComplex for Eastern Region Patna, Bihar.

Kumar, R.;K.Alama; V. V.Krishnab and K.Srinivasa.2012. Value Chain Analysis of Maize Seed Delivery System in Public and Private Sectors in Bihar. Agricultural Economics Research Review, 25:387-398.

Minten, B.; K. M. Singh and R.Sutradhar. 2010. The Makhana Value Chain in Bihar: An Assessment and Policy Implications. Article in SSRN Electronic Journal.

Rahaman, A. A. 2019. Coordination and Impact of Agrifood Value Chains on Farm Performance: Ph.D Thesis, The Institute for Food Economics and Consumption Studies of the ChristianAlbrechts-Universität Kiel Evidence from Smallholder Rice Farmers in Northern Ghana

Singh, A. 2014. Centre to boost 'makhana' cultivation. Times of India https://timesofindia.indiatimes.com/indi a/Centre-to-boost-makhana-cultivation. Accessed 31 August 2014. 


\section{How to cite this article:}

Ravi Atal, Shridhar Patil, Subodh Kumar, Suman Lata and Sonam Roy. 2020. Processing of Makhana and Value Chain Financing in Bihar. Int.J.Curr.Microbiol.App.Sci. 9(05): 1322-1326. doi: https://doi.org/10.20546/ijcmas.2020.905.147 